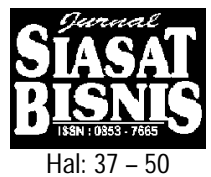

\title{
VAR PORTFOLIO OPTIMAL: PERBANDINGAN ANTARA METODE MARKOWITZ DAN MEAN ABSOLUTE DEVIATION
}

\author{
R. Agus Sartono \\ Fakultas Ekonomi Universitas Gadjah Mada
}

\author{
Arie Andika Setiawan \\ Alumni Magíster Manajemen \\ Universitas Gadjah Mada
}

\begin{abstract}
Portfolio selection method which have been introduced by Harry Markowitz (1952) used variance or deviation standard as a measure of risk. Kanno and Yamazaki (1991) introduced another method and used mean absolute deviation as a measure of risk instead of variance. The Value-at Risk (VaR) is a relatively new method to capitalized risk that been used by financial institutions. The aim of this research is compare between mean variance and mean absolute deviation of two portfolios. Next, we attempt to assess the VaR of two portfolios using delta normal method and historical simulation. We use the secondary data from the Jakarta Stock Exchange - LQ45 during 2003. We find that there is a weak-positive correlation between deviation standard and return in both portfolios. The $\mathrm{VaR}$ nolmal delta based on mean absolute deviation method eventually is higher than the VaR normal delta based on mean variance method. However, based on the historical simulation the VaR of two methods is statistically insignificant. Thus, the deviation standard is sufficient measures of portfolio risk.
\end{abstract}

Keywords: optimalisasi portofolio, mean-variance, mean-absolute deviation, value-at-risk, metode delta normal, metode simulasi historis

\section{PENDAHULUAN}

Investor dapat mengurangi risiko dengan cara melakukan diversifikasi investasi. Diversifikasi investasi akan memberikan manfaat optimum apabila return antar investasi dalam satu portfolio berkorelasi negative. Harry M. Markowitz (1952) telah membuktikan bahwa risiko berinvestasi dapat dikurangi dengan menggabungkan beberapa aset ke dalam sebuah portofolio. Metode Markowitz menunjukkan bahwa apabila aset-aset keuangan dalam suatu portofolio memiliki korelasi return yang lebih kecil dari positif satu, risiko portofolio secara keseluruhan dapat diturunkan. Risiko minimum akan dicapai apabila korelasi return investasi adalah segatif sempurna.

Selain dengan menggunakan metode mean-variance yang dikenalkan oleh Markowitz (1952), Konno dan Yamazaki (1991) mengenalkan metode Mean-Absolute Deviation (MAD) sebagai alternatif dari model yang dikenalkan oleh Markowitz (1952). Model MAD menggunakan absolute deviation sebagai parameter untuk risiko. Berbeda dengan model Mean-Variance yang merupakan permasalahan pemilihan portofolio berbentuk quadratic programming, model MAD ini merupakan permasalahan pemilihan portofolio yang berbentuk linear programming. 
Institusi-institusi finansial dan juga para investor selalu ingin berusaha agar risiko bisa selalu dikuantifikasikan. Pengukuran-pengukuran tradisional yang digunakan dalam mengkuantifikasikan risiko banyak kaitannya dengan pengukuran sensitivitas. Pengukuran risiko dengan sensitivitas memperhatikan perubahan pada salah satu faktor risiko dan dampaknya terhadap profit and loss suatu portofolio.

Pengukuran-pengukuran tradisional hanya memberikan hasil dalam bentuk jumlah kerugian yang mungkin dialami. Pengukuran-pengukuran tersebut tidak memberikan gambaran mengenai potensi atau probabilitas terjadinya kerugiankerugian tersebut. Selain itu, pengukuran-pengukuran tradisional tersebut digunakan pada aset-aset secara individual sehingga setiap aset memiliki metode pengukuran risiko secara tersendiri.

Masalah timbul ketika masing-masing aset tersebut digabungkan dalam suatu kelompok produk ataupun sebuah portofolio. Seperti yang diketahui, perlu adanya diversifikasi dalam suatu kelompok produk atau portofolio agar risiko berkurang. Pengukuran risiko menjadi sulit oleh karena banyaknya metode yang digunakan untuk mengukur risiko berbagai macam aset tersebut yang digabungkan dalam suatu kelompok produk ataupun portofolio.

Metode Value at Risk atau VaR merupakan jawaban atas kelemahan-kelemahan metode pengukuran risiko tradisional di atas. Salah satu kelebihan dari VaR adalah bahwa metode pengukuran ini dapat diaplikasikan ke seluruh produk-produk finansial yang diperdagangkan. Angka yang didapatkan merupakan hasil perhitungan secara agregat atau menyeluruh terhadap risiko produk-produk sebagai suatu kesatuan. Tentu saja hal ini lebih praktis daripada metode-metode perhitungan tradisional, yang harus diaplikasikan secara individual pada masing-masing produk.

VaR juga memberikan estimasi kemungkinan atau probabilitas mengenai timbulnya kerugian yang jumlahnya lebih besar daripada angka kerugian yang telah ditentukan. Hal ini merupakan sesuatu yang tidak didapat dari metode-metode pengukuran risiko secara tradisional. VaR juga memperhatikan perubahan harga asetaset yang ada dan pengaruhnya terhadap aset-aset yang lain. Hal ini memungkinkan dilakukannya pengukuran terhadap berkurangnya risiko yang diakibatkan oleh diversifikasi kelompok produk atau portofolio.

\section{Value at Risk}

Menurut Best (1998) Value at Risk atau VaR adalah suatu metode pengukuran risiko secara statistik yang memperkirakan kerugian maksimum yang mungkin terjadi atas suatu portofolio pada tingkat kepercayaan (level of confidence) tertentu. Nilai VaR selalu disertai dengan probabilitas yang menunjukkan seberapa mungkin kerugian yang terjadi akan lebih kecil dari nilai VaR tersebut. VaR adalah suatu nilai kerugian moneter yang mungkin dialami dalam jangka waktu yang telah ditentukan. Pernyataan berikut ini merupakan definisi formal dari VaR yang dikutip dari Best (1998): "Value at Risk is the maximum amount of money that may be lost on a portfolio over a given period of time, with a given level of confidence." Per- 
nyataan berikut ini merupakan definisi formal dari VaR yang diungkapkan oleh Jorion (2001): "VaR summarizes the worst loss over a target horizon with a given level of confidence." Butler (1999) memberikan definisi VaR sebagai berikut: "Value at Risk measures the worst expected loss that an institution can suffer over a given time interval under normal market conditions at a given confidence level. It assesses risk by using statistical and simulation models designed to capture the volatility of assets in a bank's portfolio." Dari tiga pendapat tersebut menunjukan bahwa VaR merupakan alternatif jawaban kelemahan metode Markowitz.

Dalam kaitannya dengan kemudahan pemahaman atas nilai VaR, Stambaugh (1996) menyatakan bahwa VaR memiliki fungsi sebagai berikut: "1) providing a common language for risk, 2) allowing for more effective and consistent internal risk management, risk limit setting and evaluation, 3) providing an enterprise-wide mechanism for external regulation, and 4) providing investors with an understandable tool for risk assessment."

\section{DESIGN PENELITIAN}

Penelitian ini dibuat dengan tujuan untuk melakukan perbandingan antara metode Mean-Absolute Deviation (MAD) dengan metode Mean-Variance dalam menyusun suatu portofolio yang optimal. Penekanan lebih lanjut dilakukan pada nilai VaR yang dihasilkan oleh kedua metode tersebut.

Untuk metode VaR, penulis hendak menggunakan dua metode utama dalam perhitungan $\mathrm{VaR}$, yaitu metode kovarian atau delta normal dan metode simulasi. Untuk metode simulasi, penulis memilih menggunakan metode simulasi data historis. Sebagai obyek penelitian, akan dilakukan simulasi penyusunan portofolioportofolio dari saham-saham yang ada di bursa efek Jakarta dengan menggunakan metode Mean-Variance dan metode MAD. Setelah portofolio-portofolio optimal dihasilkan, perhitungan VaR baik secara delta normal maupun historical akan diaplikasikan dalam menghitung nilai VaR dari portofolio-portofolio tersebut.

Penelitian ini menggunakan data sekunder yang berupa saham-saham yang terdaftar dalam Bursa Efek Jakarta dan termasuk dalam indeks LQ45. Data-data yang digunakan adalah nilai return saham-saham tersebut selama tahun 2003. Rumus rata-rata return adalah sebagai berikut:

$\mathrm{E}(\mathrm{r})=\frac{\sum_{t=1}^{T} r_{t}}{T}$

Notasi:

$E(r)=$ tingkat return ekspektasi untuk suatu saham

$r_{\mathrm{t}}=$ tingkat return suatu saham pada periode ke-t

$\mathrm{T}=$ jumlah total periode 


\section{PROSEDUR PENYUSUNAN PORTOFOLIO OPTIMAL}

Portofolio optimal akan disusun dengan menggunakan 2 metode, yaitu metode Mean-Variance dan metode Mean-Absolute Deviation. Portofolio akan disusun berdasarkan periode bulanan, sehingga masing-masing metode akan menghasilkan 12 buah portofolio optimal untuk tahun 2003.

\section{Penyusunan Portofolio Optimal dengan Menggunakan Metode Mean-Variance}

Metode ini mengandalkan parameter yang berupa return, varian serta kovarian dari saham-saham yang telah diseleksi. Asumsi yang digunakan dalam penggunaan metode ini adalah bahwa (i) short sale tidak diijinkan, dan (ii) investor mengabaikan simpanan dan pinjaman bebas risiko. Model optimalisasi portofolio Mean-Variance diformulasikan sebagai berikut:

Minimize $\sum_{i=1}^{n} \sum_{j=1}^{n} w_{i} \cdot w_{j} \cdot \sigma_{i j}$

Dengan kendala-kendala sebagai berikut:

$$
\begin{aligned}
& \sum_{i=1}^{n} w_{i} \cdot \bar{r}_{i} \geq \alpha \\
& \sum_{i=1}^{n} w_{i}=1 \\
& 0 \leq w_{i} \leq 1, \quad i=1, \ldots, n
\end{aligned}
$$

Notasi:

$a=$ tingkat return minimum yang dikehendaki oleh investor

$w_{i}=$ proporsi investasi pada saham $\mathrm{i}$

Penyusunan Portofolio Optimal dengan Menggunakan Metode Mean-Absolute Deviation

Metode penyusunan portofolio optimal ini pertama kali dikenalkan oleh Konno dan Yamazaki (1991). Parameter risiko yang digunakan dalam metode ini adalah Mean-Absolute Deviation (MAD). Formula perhitungan portofolio berdasarkan MAD adalah sebagai berikut:

Minimize $E\left[\left|\sum_{i=1}^{n} r_{i} \cdot w_{i}-E\left[\sum_{i=1}^{n} r_{i} \cdot w_{i}\right]\right|\right]$

Dengan kendala-kendala sebagai berikut:

$$
\sum_{i=1}^{n} \bar{r}_{i} \cdot w_{i} \geq \alpha
$$




$$
\begin{aligned}
& \sum_{i=1}^{n} w_{i}=1 \\
& 0 \leq w_{i} \leq 1, \quad i=1, \ldots, n
\end{aligned}
$$

Apabila:

$$
\bar{r}_{i}=E\left[r_{i}\right]=\sum_{i=1}^{T} r_{i t} / T
$$

Maka persamaan MAD di atas dapat diubah menjadi:

$$
E\left[\left|\sum_{i=1}^{n} r_{i} \cdot w_{i}-E\left[\sum_{i=1}^{n} r_{i} \cdot w_{i}\right]\right|\right]=\frac{1}{T} \sum_{i=1}^{T}\left|\sum_{i=1}^{n}\left(r_{i t}-\bar{r}_{i}\right) w_{i}\right|
$$

Apabila dinotasikan bahwa:

$$
a_{i t}=r_{i t}-\bar{r}_{i}, \quad i=1, \ldots, n \quad t=1, \ldots, n
$$

Maka formulasi MAD di atas menjadi:

Minimize $\sum_{t=1}^{T} \frac{\left|\sum_{i=1}^{n} a_{i t} \cdot w_{i}\right|}{T}$

Dengan kendala-kendala sebagai berikut:

$$
\begin{aligned}
& \sum_{i=1}^{n} \bar{r}_{i} . w_{i} \geq \alpha \\
& \sum_{i=1}^{n} w_{i}=1 \\
& 0 \leq w_{i} \leq 1, \quad i=1, \ldots, n
\end{aligned}
$$

Bila persamaan di atas dijadikan programasi linear, maka formula untuk perhitungan portofolio optimal berdasarkan MAD menjadi:

Minimize $\frac{\sum_{t=1}^{n} y_{1}}{T}$ 
Dengan kendala-kendala sebagai berikut:

$$
\begin{array}{ll}
y_{t}+\sum_{i=1}^{n} a_{i t} . w_{i} \geq 0, & t=1, \ldots, T, \\
y_{t}-\sum_{i=1}^{n} a_{i t} . w_{i} \geq 0, & t=1, \ldots, T, \\
\sum_{i=1}^{n} \bar{r}_{i} \cdot w_{i} \geq \alpha & \\
\sum_{i=1}^{n} w_{i}=1 & \\
0 \leq w_{i} \leq 1, \quad i=1, \ldots, n &
\end{array}
$$

Setelah kedua kelompok portofolio optimal didapatkan dengan metode Mean-Variance dan metode Mean-Absolute Deviation, langkah selanjutnya adalah menghitung nilai $\mathrm{VaR}$ kedua golongan portofolio tersebut.

\section{PERHITUNGAN VaR DENGAN METODE VARIAN-KOVARIAN}

Model varian-kovarian VaR berangkat dari asumsi bahwa persentase perubahan harga di dalam pasar keuangan memiliki distribusi yang normal. Dengan adanya asumsi ini, maka volatilitas dapat dinyatakan dalam bentuk standar deviasi. Volatilitas ini digambarkan dalam bentuk persentase perubahan harga dan persentase perubahan harga ini dinyatakan sebagai ukuran 1 standar deviasi. Sebagai contoh: berdasarkan perubahan historis persentase harga dari suatu aset didapatkan bahwa volatilitasnya adalah $5 \%$. Nilai ini disamakan dengan satu (1) standar deviasi. Rumus perhitungan nilai VaR dengan metode varian-kovarian adalah:

$\operatorname{VaR}=\alpha \sigma_{i} W$

Di mana $\alpha$ adalah standard normal deviate, $\sigma$ adalah standar deviasi dari aset individual tersebut dan $W$ adalah nilai dari aset tersebut. Nilai $\alpha$ adalah sebesar 1 bila digunakan confidence level sebesar 84\%. Untuk confidence level sebesar 95\% digunakan nilai $\alpha$ sebesar 1.645 .

\section{PERHITUNGAN VaR DENGAN METODE SIMULASI HISTORIS (HISTORICAL SIMULATION)}

Metode simulasi historis menggunakan data-data historis return dari asetaset dalam suatu portofolio dan menerapkan pembobotan terkini dari portofolio tersebut terhadap data-data historis perubahan harga aset-aset tersebut. Rumus untuk menghitung return dari metode ini adalah sebagai berikut: 


$$
R_{p, k}=\sum_{i=1}^{n} w_{i, t} R_{i, k} \quad k=1, \ldots, \mathrm{t}
$$

$\mathrm{R}_{\mathrm{p}, \mathrm{k}}$ adalah return portofolio pada periode ke- $\mathrm{k}, \mathrm{n}$ adalah banyaknya aset dalam portofolio, $\mathrm{w}_{\mathrm{i}, \mathrm{t}}$ adalah bobot aset ke-i pada periode $\mathrm{t}$ (periode terkini) dan $\mathrm{R}_{\mathrm{i}, \mathrm{k}}$ adalah return dari aset ke-i pada periode ke-k. Perhatikan bahwa bobot yang digunakan adalah bobot pada periode terkini, yaitu periode $t$.

\section{HASIL PERHITUNGAN DAN ANALISA}

Hasil Penyusunan Portofolio Optimal dengan Menggunakan Metode Markowitz atau Mean-Variance dan Metode Mean-absolute Deviation

Dalam penyusunan portofolio untuk kedua metode, dibutuhkan tingkat return minimum atau a. Untuk a digunakan tingkat bunga Sertifikat Bank Indonesia atau SBI selama tahun 2003. Berikut ini adalah tabel tingkat bunga bulanan SBI selama tahun 2003. Tabel 1 . berikut ini menyajikan hasil penyusunan portofolioportofolio optimal baik berdasarkan metode mean-variance maupun metode MeanAbsolute Deviation.

Tabel 1: Hasil Penyusunan Portofolio-Portofolio Optimal

\begin{tabular}{|l|c|c|c|c|c|}
\hline \multirow{2}{*}{ Bulan } & \multirow{2}{*}{ SBI } & \multicolumn{2}{c|}{ Markowitz } & \multicolumn{2}{c|}{ MAD } \\
\cline { 3 - 6 } & & $\begin{array}{c}\text { Standar } \\
\text { Deviasi }\end{array}$ & \multicolumn{1}{c|}{ Return } & $\begin{array}{c}\text { Standar } \\
\text { Deviasi }\end{array}$ & Return \\
\hline Januari & $1.07 \%$ & $5.1923 \%$ & $1.0665 \%$ & $5.2273 \%$ & $1.0665 \%$ \\
\hline Februari & $1.04 \%$ & $0.8293 \%$ & $1.0413 \%$ & $1.0000 \%$ & $1.0411 \%$ \\
\hline Maret & $0.96 \%$ & $3.6048 \%$ & $0.8500 \%$ & $3.6050 \%$ & $0.8500 \%$ \\
\hline April & $0.94 \%$ & $0.7334 \%$ & $0.9368 \%$ & $0.7798 \%$ & $0.9369 \%$ \\
\hline Mei & $0.90 \%$ & $0.7726 \%$ & $0.8997 \%$ & $0.8429 \%$ & $0.8997 \%$ \\
\hline Juni & $0.82 \%$ & $1.4896 \%$ & $0.8246 \%$ & $1.6966 \%$ & $0.8247 \%$ \\
\hline Juli & $0.77 \%$ & $1.2051 \%$ & $0.7668 \%$ & $1.3627 \%$ & $0.7669 \%$ \\
\hline Agustus & $0.75 \%$ & $0.7366 \%$ & $0.7499 \%$ & $0.8396 \%$ & $0.7497 \%$ \\
\hline September & $0.73 \%$ & $0.6845 \%$ & $0.7281 \%$ & $0.8793 \%$ & $0.7283 \%$ \\
\hline Oktober & $0.71 \%$ & $0.7299 \%$ & $0.7107 \%$ & $0.8352 \%$ & $0.7106 \%$ \\
\hline November & $0.71 \%$ & $1.8245 \%$ & $0.7061 \%$ & $2.0779 \%$ & $0.7062 \%$ \\
\hline Desember & $0.70 \%$ & $0.3288 \%$ & $0.6994 \%$ & $0.4298 \%$ & $0.7025 \%$ \\
\hline
\end{tabular}

Hasil portofolio optimal pada bulan Maret tidak menggunakan tingkat suku bunga SBI yang sebesar 0,96\% sebagai persyaratan minimum tingkat return, baik pada metode Markowitz maupun MAD. Hal ini dikarenakan tingkat suku bunga SBI pada bulan Maret 2003 terlalu tinggi bila dibandingkan dengan tingkat return semua saham LQ45. Persyaratan tingkat return minimum diturunkan menjadi 0,85\% untuk bulan Maret 2003 sehingga portofolio optimal untuk kedua metode dapat dihasilkan. 


\section{Hasil Perhitungan Nilai Value-at-Risk}

Seperti yang telah disebutkan dalam bagian sebelumnya, perhitungan VaR dilakukan dengan dua metode. Kedua metode tersebut adalah metode delta normal dan metoda simulasi historis. Perhitungan nilai standar deviasi untuk portofolioportofolio yang dihasilkan dengan menggunakan metode Mean-Absolute Deviation dilakukan dengan menggunakan metode perhitungan risiko mean-variance yang diperkenalkan oleh Markowitz (1952). Hal ini dilakukan karena dalam perhitungan VaR dengan metode varian-kovarian, parameter risiko yang digunakan adalah standar deviasi dan bukan Mean-Absolute Deviation atau MAD. Tabel 2. menyajikan hasil perhitungan nilai VaR delta normal untuk portofolio-portofolio optimal yang dihasilkan oleh kedua metode tersebut.

Tabel 2: Hasil Perhitungan Nilai VaR pada Portofolio-Portofolio Optimal dengan Menggunakan Metode Delta Normal atau Varian-Kovarian

\begin{tabular}{|l|c|c|c|c|}
\hline \multirow{2}{*}{\multicolumn{1}{c|}{ Bulan }} & \multicolumn{2}{c|}{ Markowitz } & \multicolumn{2}{c|}{ MAD } \\
\cline { 2 - 5 } & Standar Deviasi & VaR & Standar Deviasi & VaR \\
\hline Januari & $5.1923 \%$ & $8.5413 \%$ & $5.2273 \%$ & $8.5989 \%$ \\
\hline Februari & $0.8293 \%$ & $1.3641 \%$ & $1.0000 \%$ & $1.6450 \%$ \\
\hline Maret & $3.6048 \%$ & $5.9299 \%$ & $3.6050 \%$ & $5.9302 \%$ \\
\hline April & $0.7334 \%$ & $1.2065 \%$ & $0.7798 \%$ & $1.2828 \%$ \\
\hline Mei & $0.7726 \%$ & $1.2709 \%$ & $0.8429 \%$ & $1.3865 \%$ \\
\hline Juni & $1.4896 \%$ & $2.4505 \%$ & $1.6966 \%$ & $2.7910 \%$ \\
\hline Juli & $1.2051 \%$ & $1.9823 \%$ & $1.3627 \%$ & $2.2417 \%$ \\
\hline Agustus & $0.7366 \%$ & $1.2117 \%$ & $0.8396 \%$ & $1.3811 \%$ \\
\hline September & $0.6845 \%$ & $1.1259 \%$ & $0.8793 \%$ & $1.4464 \%$ \\
\hline Oktober & $0.7299 \%$ & $1.2006 \%$ & $0.8352 \%$ & $1.3739 \%$ \\
\hline November & $1.8245 \%$ & $3.0012 \%$ & $2.0779 \%$ & $3.4181 \%$ \\
\hline Desember & $0.3288 \%$ & $0.5409 \%$ & $0.4298 \%$ & $0.7070 \%$ \\
\hline
\end{tabular}

Perhitungan nilai $\mathrm{VaR}$ dengan metode simulasi historis dilakukan dengan menggunakan rumus yang telah dibahas sebelumnya. Data historis return saham yang digunakan adalah sebanyak 100 hari. Confidence level yang digunakan dalam perhitungan nilai VaR dengan metode simulasi historis ini adalah 95\%.

Tabel 3 menyajikan hasil perhitungan nilai VaR metode simulasi historis pada portofolio-portofolio optimal tersebut. Dari Tabel 3 tampak bahwa metode Mean-Absolute-Deviation memberikan hasil secara yang lebih rendah dari pada metode Markowitz. Hanya untuk bulan Juni, Oktober dan November saja yang memberikan hasil lebih tinggi. Hal ini berarti bahwa secara umum metode Mean Absolute Deviation memberikan hasil yang lebih baik jika dibanding dengan metode Markowitz.. 
Tabel 3: Hasil Perhitungan Nilai VaR Portofolio-Portofolio Optimal dengan Menggunakan Metode Simulasi Historis

\begin{tabular}{|l|c|c|}
\hline \multicolumn{1}{|c|}{ Bulan } & Markowitz & MAD \\
\hline Januari & -0.05443 & -0.05229 \\
\hline Februari & -0.04194 & -0.03900 \\
\hline Maret & -0.04739 & -0.04739 \\
\hline April & -0.01807 & -0.01717 \\
\hline Mei & -0.01966 & -0.01716 \\
\hline Juni & -0.02169 & -0.02733 \\
\hline Juli & -0.01815 & -0.01635 \\
\hline Agustus & -0.01776 & -0.01717 \\
\hline September & -0.01944 & -0.01650 \\
\hline Oktober & -0.01657 & -0.01801 \\
\hline November & -0.02224 & -0.02415 \\
\hline Desember & -0.01803 & -0.01823 \\
\hline
\end{tabular}

\section{Analisa Korelasi antara Return dan Risiko Portofolio Optimal}

Pada analisa ini, pengujian dilakukan dengan menghitung pearson correlation coefficient antara nilai return dan risiko yang berupa standar deviasi dari portofolio-portofolio tersebut. Uji statistik dilakukan dengan menggunakan confidence level sebesar $95 \% . \mathrm{H}_{0}$ adalah bahwa tidak ada korelasi antara nilai return dan standar deviasi. $\mathrm{H}_{1}$ adalah adanya korelasi antara nilai return dan standar deviasi. Rincian ini berlaku baik pada uji korelasi pada portofolio optimal metode meanvariance maupun metode MAD. Tabel 4 menyajikan hasil analisa korelasi antara return dan risiko dari portofolio-portofolio yang dihasilkan dengan menggunakan metode mean-variance Markowitz (1952).

Tabel 4: Hasil Analisa Korelasi antara Return dan Standar Deviasi PortofolioPortofolio Optimal Metode Mean-variance

\begin{tabular}{|ll|r|r|}
\hline & & RET_MAR & SD_MAR \\
\hline RET_MAR & Pearson Correlation & 1 & .489 \\
& Sig. (2-tailed) &. & .107 \\
& $\mathrm{~N}$ & 12 & 12 \\
SD_MAR & Pearson Correlation & .489 & 1 \\
& Sig. (2-tailed) & .107 &. \\
& $\mathrm{~N}$ & 12 & 12 \\
\hline
\end{tabular}

Dari Tabel 4 dapat dilihat bahwa nilai pearson correlation antara nilai return dan nilai standar deviasi adalah sebesar 0.489 menunjukkan tingkat hubungan yang sedang. Namun untuk nilai sampel sebesar 12 dibutuhkan nilai korelasi minimal 
0.576 untuk dapat mengambil kesimpulan adanya korelasi antara dua variabel. Hal ini juga didukung dengan nilai signifikansi hasil uji korelasi tersebut yang sebesar 0.107 . Nilai ini lebih besar daripada 0.05 yang merupakan nilai batas signifikansi pada confidence level sebesar $95 \%$. Hal ini menunjukkan bahwa $\mathrm{H}_{0}$ diterima dan $\mathrm{H}_{1}$ ditolak. Dengan kata lain, tidak ada korelasi antara nilai return dengan nilai standar deviasi pada portofolio-portofolio optimal hasil metode mean-variance.

Tabel 5: Hasil Analisa Korelasi antara Return dan Standar Deviasi PortofolioPortofolio Optimal Metode Mean-absolute Deviation

\begin{tabular}{|l|l|r|r|}
\hline \multicolumn{2}{|l|}{} & RET_MAD & SD_MAD \\
\hline RET_MAD & $\begin{array}{l}\text { Pearson } \\
\text { Correlation }\end{array}$ & 1 & .476 \\
\cline { 2 - 4 } & Sig. (2-tailed) &. & .118 \\
\cline { 2 - 4 } & $\mathrm{N}$ & 12 & 12 \\
\hline SD_MAD & Pearson & .476 & 1 \\
& Correlation & .118 &. \\
\cline { 2 - 4 } & Sig. (2-tailed) & 12 & 12 \\
\cline { 2 - 4 } & $\mathrm{N}$ & & \\
\hline
\end{tabular}

Uji korelasi yang sama juga diterapkan pada portofolio-portofolio optimal hasil metode mean-absolute deviation. Tabel 5 di atas menyajikan hasil uji korelasi tersebut. Dari Tabel 5 di atas dapat dilihat bahwa nilai pearson correlation antara nilai return dan nilai standar deviasi adalah sebesar 0.476 menunjukkan tingkat hubungan yang sedang. Namun seperti analisis sebelumnya, untuk nilai sampel sebesar 12 dibutuhkan nilai korelasi minimal 0.576 untuk dapat mengambil kesimpulan adanya korelasi antara dua variabel. Hal ini juga didukung dengan nilai signifikansi hasil uji korelasi tersebut yang sebesar 0.118. Nilai ini lebih besar daripada 0.05 yang merupakan nilai batas signifikansi pada confidence level sebesar 95\%. Hal ini menunjukkan bahwa $\mathrm{H}_{0}$ diterima dan $\mathrm{H}_{1}$ ditolak. Dengan kata lain, tidak ada korelasi yang kuat antara nilai return dengan nilai standar deviasi pada portofolio-portofolio optimal hasil metode mean-absolute deviation.

\section{Perbandingan Uji Rata-Rata antara Nilai Standar Deviasi Hasil Metode Optimalisasi Portofolio Mean-Variance dan Mean-Absolute Deviation}

Pada analisa ini dilakukan pengujian perbandingan rata-rata atau mean comparation antara nilai risiko yang direpresentasikan dalam bentuk standar deviasi yang dihasilkan dengan metode Mean-Variance dan Mean-Absolute Deviation. Uji statistik dilakukan pada confidence level $95 \%$. $\mathrm{H}_{0}$ adalah bahwa tidak ada perbedaan nilai standar deviasi antara kedua metode optimalisasi. Sedangkan $\mathrm{H}_{1}$ adalah bahaw ada perbedaan nilai standar deviasi antara kedua metode optimalisasi portofolio tersebut. Tabel 6 dan Tabel 7 berikut ini menyajikan hasil analisa uji perbandingan 
rata-rata nilai standar deviasi yang dihasilkan oleh kedua metode optimalisasi portofolio tersebut.

Tabel 6: Hasil Analisa Uji Perbandingan Rata-Rata Nilai Standar Deviasi yang Dihasilkan oleh Metode Optimalisasi Portofolio Mean-variance dan Mean-absolute Deviation

\begin{tabular}{|c|c|c|c|c|c|c|c|c|}
\hline & \multicolumn{5}{|c|}{ Paired Differences } & \multirow[t]{3}{*}{$\mathrm{t}$} & \multirow[t]{3}{*}{ df } & \multirow[t]{3}{*}{$\begin{array}{l}\text { Sig. (2- } \\
\text { tailed) }\end{array}$} \\
\hline & \multirow[t]{2}{*}{ Mean } & \multirow[t]{2}{*}{$\begin{array}{c}\text { Std. } \\
\text { Deviation }\end{array}$} & \multirow[t]{2}{*}{$\begin{array}{l}\text { Std. Error } \\
\text { Mean }\end{array}$} & \multicolumn{2}{|c|}{$\begin{array}{c}95 \% \text { Confidence Interval } \\
\text { of the Difference }\end{array}$} & & & \\
\hline & & & & Lower & Upper & & & \\
\hline $\begin{array}{cc}\text { Pair } 1 & \text { SD_MAR - } \\
\text { SD_MAD }\end{array}$ & -.001204 & .000771 & .000222 & -.001694 & -.000714 & -5.413 & 11 & .000 \\
\hline
\end{tabular}

Tabel 7: Data Statistik Uji Perbandingan Rata-Rata Nilai Standar Deviasi

\begin{tabular}{|cc|c|c|c|c|}
\hline & & Mean & N & Std. Deviation & Std. Error Mean \\
\hline Pair 1 & SD_MAR & .0151094184 & 12 & .01447047011 & .00417726491 \\
& SD_MAD & .0163133461 & 12 & .01417979443 & .00409335407 \\
\hline
\end{tabular}

Hasil pengujian di atas menunjukkan bahwa nilai signifikansi lebih kecil dari 0.05. Dengan demikian, $\mathrm{H}_{0}$ ditolak dan $\mathrm{H}_{1}$ diterima. Hal ini menunjukkan adanya perbedaan antara nilai standar deviasi yang dihasilkan oleh metode optimalisasi portofolio Mean-Variance dengan metode Mean-Absolute Deviation. Dari tabel 7 dapat dilihat bahwa nilai standar deviasi dari portofolio-portofolio optimal yang dihasilkan dengan metode optimalisasi Mean-Absolute Deviation memiliki rata-rata yang lebih tinggi daripada nilai standar deviasi dari portofolio-portofolio optimal yang dihasilkan dengan metode optimalisasi Mean-Variance.

\section{Perbandingan Uji Rata-Rata antara Nilai VaR Hasil Metode Optimalisasi Portofolio Mean-variance dan Mean-Absolute Deviation}

Pada analisa ini dilakukan pengujian perbandingan rata-rata atau mean comparation antara nilai VaR yang dihasilkan dengan metode Mean-Variance dan Mean-Absolute Deviation. Nilai VaR yang diuji adalah nilai VaR yang dihasilkan baik oleh metode delta normal maupun metode simulasi historis. Pengujian dilakukan pada tingkat confidence level sebesar $95 \%$ dengan $\mathrm{H}_{0}$ menyatakan bahwa tidak ada perbedaan nilai VaR antara kedua metode optimalisasi portofolio. $H_{1}$ menyatakan bahwa ada perbedaan nilai VaR antara kedua metode optimalisasi.

Rincian di atas berlaku atas pengujian perbandingan rata-rata baik terhadap nilai VaR metode delta normal maupun nilai VaR metode simulasi historis. Tabel 8 dan Tabel 9 berikut ini menyajikan hasil analisa uji perbandingan rata-rata nilai VaR delta normal yang dihasilkan oleh kedua metode optimalisasi portofolio. 
Tabel 8: Hasil Analisa Uji Perbandingan Rata-Rata Nilai VaR Delta Normal yang Dihasillkan Oleh Metode Optimalisasi Portofolio Mean-variance dan Mean-absolute Deviation

\begin{tabular}{|c|c|c|c|c|c|c|c|c|c|}
\hline & \multicolumn{5}{|c|}{ Paired Differences } & \multirow[t]{3}{*}{$\mathrm{t}$} & \multirow[t]{3}{*}{ df } & \multirow{3}{*}{$\begin{array}{l}\text { Sig. (2- } \\
\text { tailed) }\end{array}$} \\
\hline & & \multirow[t]{2}{*}{ Mean } & \multirow[t]{2}{*}{$\begin{array}{c}\text { Std. } \\
\text { Deviation }\end{array}$} & \multirow[t]{2}{*}{$\begin{array}{l}\text { Std. Error } \\
\text { Mean }\end{array}$} & \multicolumn{2}{|c|}{\begin{tabular}{|c|}
$95 \%$ Confidence Interval \\
of the Difference
\end{tabular}} & & & \\
\hline & & & & & Lower & Upper & & & \\
\hline Pair & $\begin{array}{l}\text { VAR_MAR - } \\
\text { VAR_MAD }\end{array}$ & -.001980 & .001268 & .000366 & -.002786 & -.001175 & -5.413 & 11 & .000 \\
\hline
\end{tabular}

Tabel 9: Data Statistik Uji Perbandingan Rata-Rata Nilai VaR Delta Normal

\begin{tabular}{|cc|c|c|c|c|}
\hline & & Mean & N & Std. Deviation & Std. Error Mean \\
\hline Pair 1 & VAR_MAR & .0248549935 & 12 & .02380392302 & .00687160068 \\
& VAR_MAD & .0268354545 & 12 & .02332576203 & .00673356749 \\
\hline
\end{tabular}

Hasil pengujian di atas menunjukkan bahwa nilai signifikansi lebih kecil dari 0.05. Dengan demikian, $\mathrm{H}_{0}$ ditolak dan $\mathrm{H}_{1}$ diterima. Hal ini menunjukkan adanya perbedaan antara nilai $\mathrm{VaR}$ delta normal yang dihasilkan oleh metode MeanVariance dengan metode Mean-Absolute Deviation. Dari tabel 9 dapat dilihat bahwa nilai $\mathrm{VaR}$ delta normal dari portofolio-portofolio optimal yang dihasilkan dengan metode optimalisasi Mean-Absolute Deviation memiliki rata-rata yang lebih tinggi daripada nilai VaR delta normal dari portofolio-portofolio optimal yang dihasilkan dengan metode optimalisasi Mean-Variance.

Tabel 10 dan Tabel 11 menyajikan hasil analisa uji perbandingan rata-rata nilai VaR simulasi historis yang dihasilkan oleh kedua metode optimalisasi portofolio.

Tabel 10: Hasil Analisa Uji Perbandingan Rata-Rata Nilai VaR Simulasi Historis yang Dihasilkan Oleh Metode Optimalisasi Portofolio Mean-variance dan Mean-absolute Deviation

\begin{tabular}{|c|c|c|c|c|c|c|c|c|c|}
\hline & \multicolumn{5}{|c|}{ Paired Differences } & \multirow[t]{3}{*}{$\mathrm{t}$} & \multirow[t]{3}{*}{ df } & \multirow{3}{*}{$\begin{array}{l}\text { Sig. (2- } \\
\text { tailed) }\end{array}$} \\
\hline & & \multirow[t]{2}{*}{ Mean } & \multirow[t]{2}{*}{$\begin{array}{c}\text { Std. } \\
\text { Deviation }\end{array}$} & \multirow[t]{2}{*}{$\begin{array}{l}\text { Std. Error } \\
\text { Mean }\end{array}$} & \multicolumn{2}{|c|}{\begin{tabular}{|c|}
$95 \%$ Confidence Interval \\
of the Difference
\end{tabular}} & & & \\
\hline & & & & & Lower & Upper & & & \\
\hline Pair 1 & $\begin{array}{l}\text { HIS_MAR - } \\
\text { HIS MAD }\end{array}$ & -.000384 & .002491 & .000719 & -.001966 & .001199 & -.534 & 11 & .604 \\
\hline
\end{tabular}

Tabel 11: Data Statistik Uji Perbandingan Rata-Rata Nilai VaR Delta Normal

\begin{tabular}{|c|c|c|c|c|c|}
\hline & & Mean & $\mathrm{N}$ & Std. Deviation & Std. Error Mean \\
\hline \multirow[t]{2}{*}{ Pair 1} & HIS_MAR & -.0262798770 & 12 & .01341501647 & .00387258169 \\
\hline & HIS_MAD & -.0258963206 & 12 & .01301956586 & .00375842493 \\
\hline
\end{tabular}


Hasil pengujian di atas menunjukkan bahwa nilai signifikansi lebih besar dari 0.05. Dengan demikian, $\mathrm{H}_{0}$ diterima dan $\mathrm{H}_{1}$ ditolak. Hal ini menunjukkan tidak adanya perbedaan antara nilai VaR simulasi historis yang dihasilkan oleh metode Mean-Variance dengan metode Mean-Absolute Deviation. Dari tabel 11 dapat dilihat bahwa nilai VaR delta normal dari portofolio-portofolio optimal yang dihasilkan dengan metode optimalisasi Mean-Absolute Deviation memiliki rata-rata yang lebih rendah daripada nilai $\mathrm{VaR}$ delta normal dari portofolio-portofolio optimal yang dihasilkan dengan metode optimalisasi Mean-Variance.

\section{KESIMPULAN}

Berdasarkan proses pengolahan data dan analisa data yang telah dibahas dalam bagian terdahulu, dapat diambil beberapa kesimpulan berikut:

1. Metode optimalisasi portofolio yang dikenalkan oleh Markowitz (1952) yaitu metode Mean-Variance menghasilkan portofolio-portofolio yang komposisinya berbeda dengan portofolio-portofolio yang dihasilkan oleh metode optimalisasi Mean-Absolute Deviation yang dikenalkan oleh Konno dan Yamazaki (1991).

2. Metode Mean-Variance menghasilkan portofolio-portofolio yang nilai standar deviasinya rata-rata sedikit lebih kecil daripada portofolio-portofolio yang dihasilkan dengan metode Mean-AbsoluteDdeviation. Dengan kata lain, tingkat risiko yang dihasilkan kedua metode optimalisasi tersebut berbeda satu dengan yang lainnya.

3. Ada korelasi positif antara standar deviasi dan return portofolio, baik pada portofolio-portofolio yang dihasilkan metode Mean-Variance maupun metode Mean-Absolute Deviation. Namun secara statistik, korelasi ini tidak cukup kuat. Dapat disimpulkan bahwa standar deviasi tidak cukup baik sebagai tolok ukur risiko suatu portofolio.

4. Pada analisa hasil perhitungan nilai VaR dengan metode delta normal didapat bahwa portofolio-portofolio hasil metode Mean-Variance memiliki nilai VaR delta normal yang rata-rata lebih rendah bila dibandingkan dengan portofolioportofolio yang dihasilkan dengan metode Mean-Absolute Deviation. Bila dibandingkan dengan analisa hasil perhitungan standar deviasi, dapat dilihat sebuah kesamaan di mana nilai standar deviasi secara rata-rata pada metode Mean-Variance lebih rendah daripada nilai standar deviasi pada metode MeanAbsolute Deviation. Hal ini memungkinkan karena perhitungan nilai VaR delta normal didasarkan pada nilai standar deviasi.

5. Pada analisa hasil perhitungan nilai $\mathrm{VaR}$ dengan metode simulasi historis didapat bahwa tidak ada perbedaan nilai VaR simulasi historis antara portofolioportofolio hasil metode Mean-Variance dan MeanAabsolute Deviation. Karena perhitungan nilai $\mathrm{VaR}$ simulasi historis menggunakan data-data historis yang aktual, dapat dikatakan bahwa nilai VaR yang dihasilkan pada metode ini lebih akurat bila dibandingkan dengan nilai VaR hasil metode delta normal. 


\section{DAFTAR PUSTAKA}

Best, Philip, (1998). Implementing Value at Risk, John Wiley \& Sons Ltd, England.

Butler, Cormac, (1999). Mastering Value at Risk, Pearson Education Limited, Great Britain.

Husnan, S., (1994). Dasar-dasar Teori Portofolio dan Analisis Sekuritas, Edisi Kedua, Unit Penerbit dan Percetakan AMP YKPN, Yogyakarta.

Jogiyanto H. M., (2000). Teori Portofolio dan Analisis Investasi, Edisi ke-2, BPPE, Yogyakarta.

Jones, Charles P., (2004). Investments, $9^{\text {th }}$ edition, John Wiley \& Sons, Inc., New Jersey.

Jorion, Phillipe, (2002). Value at Risk: The New Benchmark for Managing Financial Risk, The McGraw-Hill Companies, Inc,.

Konno, H. dan H. Yamazaki, (1991). "Mean-absolute Deviation Portfolio Optimization Model and Its Application to Tokyo Stock Exchange," Management Science, Vol. 37, No. 5. pp 519-531.

Markowitz, H., (1952). "Portfolio Selection," Journal of Finance, Vol. VII, No. 1, pp. 77-91.

Stambaugh, F., (1996). "Risk and value at risk," European Management Journal. Vol. 14, pp. 612-621. 